\title{
United States - Sunset Review of Anti-Dumping Duties on Corrosion-Resistant Carbon Steel Flat Products From Japan (AB-2003-5, WT/DS244/AB/R): A Legal and Economic Analysis of the Appellate Body Ruling
}

\author{
ROBERT HOWSE* \\ University of Michigan Law School \\ ROBERT W. STAIGER* \\ University of Wisconsin
}

\section{Introduction}

The WTO Anti-Dumping (AD) Agreement requires that anti-dumping duties be reviewed at least every five years (Art. 11.3); pursuant to this requirement, domestic trade authorities in the United States are charged with the task of making a determination as to whether, after five years, revoking the duties would be likely to lead to continuation or recurrence of dumping (Commerce) and of material injury (US International Trade Commission, or USITC). This is called a Sunset Review; a negative determination of likelihood, either with respect to dumping or injury, will result in the duties expiring, the "sun" setting, as it were.

The WTO Appellate Body (AB) ruling that is the subject of this chapter resulted from a challenge by Japan to a number of aspects of Commerce's approach to the Sunset Review undertaken with regard to anti-dumping duties that had been imposed on certain steel

* We thank participants at ALI meetings, where we presented this paper, for helpful comments. 
imports. Japan challenged both the general administrative practice of the Commerce Department as codified in that department's Sunset Policy Bulletin, and also the methodologies actually applied by Commerce in this particular investigation, in coming to its conclusions.

\section{Legal issues}

2.1 When can legal norms "as such" be challenged as violations of WTO rules, independent of their application?

In the Panel proceeding below, Japan argued that the United States Department of Commerce (USDOC) Sunset Policy Bulletin "as such" violated provisions of the Anti-Dumping Agreement. The Panel below made the finding that it did not have the jurisdiction to consider the Sunset Policy Bulletin "as such," because the Bulletin was not a mandatory measure and only mandatory measures could give rise to a violation of a WTO Agreement. Japan appealed these findings of the Panel.

In considering Japan's appeal, the $\mathrm{AB}$ observed that the wording of the Panel report appeared to confuse or conflate different issues: first of all, whether, in general, a measure must mandate a course of conduct in order to be subject to a WTO dispute settlement complaint; second, whether, in particular, when the measure challenged is a legal instrument "as such," it must be mandatory in order to be challengeable; third, whether, even if challengeable, a legal instrument "as such" must mandate official conduct violating WTO rules in order to be found in breach of those rules.

The $\mathrm{AB}$ then proceeded to treat these issues as analytically distinct. On the first issue, the AB held, citing DSU 3.3, that any measure that impaired benefits accruing to another WTO Member directly or indirectly could be the subject of a dispute complaint. "In principle, any act or omission attributable to a WTO member can be a measure of that Member for purposes of dispute settlement proceedings.'[Footnote omitted]

This finding is obviously correct: neither the relevant WTO treaty provisions on dispute settlement limit state responsibility in the WTO to measures that mandate a course of conduct, nor do the general background rules of state responsibility as reflected in the International Law Commission (ILC) Articles and the jurisprudence of international 
tribunals impose this kind of limitation. ${ }^{1}$ Moreover, restricting state responsibility in the WTO to acts of states that mandate a course of conduct would render unenforceable, or severely circumscribe, many provisions in the WTO treaties. For example, the Technical Barriers to Trade Agreement imposes a variety of obligations on WTO Members that concern voluntary standard-setting activities both domestic and international; these obligations are clearly distinguished from those that apply to mandatory regulatory measures: "regulations." Also, many subsidy measures that fall within the Subsidies and Countervailing Measures (SCM) Agreement do not mandate a course of conduct; a subsidy is defined in the Agreement as a financial contribution that confers a benefit. While some subsidy measures mandate a course of conduct (for instance, export performance), many do not.

On the second issue, whether legal instruments must mandate conduct that violates a WTO treaty provision in order to be challengeable "as such," the $\mathrm{AB}$ began by stating the rationale for allowing challenges to "instruments of a Member containing rules or norms ...., irrespective of how or whether those rules or norms are applied in a particular instance." According to the $\mathrm{AB}$, "the disciplines of the General Agreement on Tariffs and Trade (GATT) and the WTO, as well as the dispute settlement system, are intended to protect not only existing trade but also the security and predictability needed to conduct future trade. This objective would be frustrated if instruments setting out rules or norms inconsistent with a Member's obligations could not be brought before a Panel once they have been adopted and irrespective of any particular instance of application of such rules or norms." [Footnote omitted.]

The $\mathrm{AB}$ thus clearly endorsed a default rule that rule- or normcreating instruments may be challenged "as such" in a WTO dispute settlement. This default rule is subject only to any treaty provision of contrary effect. The $\mathrm{AB}$ then went on to consider whether the $\mathrm{AD}$ Agreement contained any such provision of contrary effect; the $\mathrm{AB}$ noted that in the US-1916 Act case it had already decided this question in the negative. In this connection, the $\mathrm{AB}$ noted that Art. 17.3 of the $\mathrm{AD}$ Agreement provided for consultations - the first stage of

${ }^{1}$ See ILC Art. 2: state responsibility is incurred by any "action or omission" that is attributable to a state and that is a breach of an international obligation. There is no distinction between mandatory and other acts of states. In the Iran Hostage case, the International Court of Justice suggested that in some circumstances mere governmental encouragement or endorsement of the conduct of private actors could give rise to state responsibility. 
dispute settlement - when a Member considered that measures taken by another Member impaired benefits accruing to it under the treaty, without in any way qualifying or restricting the concept of "measures." Secondly, the AB observed that Art. 18.4 of the AD Agreement required Members to take all necessary steps "of a general or particular character" to ensure that their "laws, regulations and administrative procedures" conformed to the $\mathrm{AD}$ Agreement.

In the AB's view, this provision not only makes it clear that the AD Agreement contemplates no departure from the default rule of state responsibility for rules and norms "as such," but in addition, that the $\mathrm{AD}$ Agreement takes a broad view of the nature of such rules or norms; the language "administrative procedures" suggesting to the AB that any "administrative instrument issued by an executive agency pursuant to statutory and regulatory provisions" (para. 84, AB report) can be challenged "as such" under the AD Agreement.

Now the $A B$ went on to consider the third issue: does a legal instrument being challenged "as such" have to mandate a course of official conduct violating the WTO rules, in order for the instrument "as such" to be found in breach of those rules? The AB noted that the "mandatory/discretionary distinction" had been used as an "analytical tool" by panels in determining whether "legislation as such" violated a particular WTO rule. The AB considered that it had, in previous cases, skirted the issue of whether mandatoriness was a necessary criterion for finding that "legislation as such" violated a WTO treaty. While stating that it was going to continue to skirt the issue, the $\mathrm{AB}$ nevertheless observed that the import of the "mandatory/discretionary distinction," like that of any other "analytical tool" would vary from case to case. In other words, depending on the treaty provision at issue, and the nature of the measure, whether the legislation as such mandated a violation of the WTO rules might or might not be of decisive importance in finding a violation. This accords with the approach to the mandatory/discretion distinction in the Section 301 case, where the Panel held that, at least in respect of some provisions of WTO treaties, "legislation as such" could constitute a violation even if it was not, strictly speaking, "mandatory." In any case, by placing such emphasis on the status of the mandatory/discretionary distinction as an "analytical tool," the $\mathrm{AB}$ is telling us what the distinction is not: it is not a metarule that overrides or precludes the determination of state responsibility based on a reading of WTO treaty provisions. Again, this seems to endorse, if only implicitly, the jurisprudence of the 
Section 301 Panel, which regarded the mandatory/discretionary distinction as merely one, albeit important, heuristic for determining whether, in a particular case, a specific provision of a WTO treaty creates state responsibility for legal instruments "as such," independent of their application. In sum, although the $\mathrm{AB}$ explicitly denied that it was going in this case to "pronounce generally upon the continuing relevance or significance of the mandatory/discretionary distinction"(para. 93), it ended up giving important guidance on the legal status or character of that distinction.

After these general remarks about the mandatory/discretionary distinction, the $\mathrm{AB}$ went on to review the Panel's characterization of the Sunset Policy Bulletin as not "a legal instrument that operates so as to mandate a course of action." (Panel Report, para. 7.126). It appears that one reason that the Panel characterized the Sunset Policy Bulletin as "non-mandatory" was the Panel's view that the Bulletin did not operate independently from other legal instruments, namely the Statute and Regulations. Here it is very difficult indeed to understand the Panel's reasoning. The Panel was trying to determine whether a particular instrument mandated a course of action in the US legal system: it then seems to have invented a test which, as far as we know, is entirely alien to US administrative law, and one that, in fact, would be fatal to all delegated rulemaking - for all such rules depend by definition on authority delegated from some higher statutory framework, and thus are not independent or autonomous, as the Panel appeared to understand these terms.

Surprisingly, the AB did not explicitly address or overturn the Panel's finding that, to be mandatory, a legal instrument must be independent or autonomous, and not a derivative from some other legal framework. Instead, the $\mathrm{AB}$ noted language in the introductory provisions of the Bulletin indicating that the Bulletin addresses "methodological or analytical issues not explicitly addressed by the statute and regulations." ( $\mathrm{AB}$ Report, para. 95). The AB appears to have understood the Panel's test as one that went to whether a legal instrument has different content from other instruments, not whether its authority is derivative from those other instruments. But the Panel's point seemed to be this: delegated rulemaking cannot be challenged "as such" at the WTO - one must either make a claim of WTO violation against the legislation delegating the rulemaking authority "as such," or a claim against individual acts derivative from that legislation that violate WTO law. "Policies" are either mandated by the legislation as such, and then the 
legislation as such is challengeable, or they are the products of delegated discretion under the legislation, in which case only individual acts of discretionary authority may be challenged.

The main problem with the Panel's approach, obviously informed by a rigid view of the mandatory/discretionary distinction - a rigid view that the $\mathrm{AB}$ clearly rejects in general - is that it doesn't reflect the way in which public law actually operates in the United States ${ }^{2}$ and indeed in other jurisdictions as well. ${ }^{3}$ As Peter Strauss observes, in the United States system, material such as "statements of policy, interpretations, staff manuals, and instructions that affect members of the public ... has the force and effect of law in most cases...'(p. 806).

Moreover, as Nina Mendelson ${ }^{4}$ points out, even though agencies are creatures of statute, a statute may grant to an agency the discretion to bind itself, i.e. to create rules that are mandatory and that the agency must follow in its future activity, but whose binding character flows from the agency itself. At the same time, as Mendelson also notes, agencies may issue policy statements, interpretations, and other material that the agency clearly indicates are not binding on its future actions. In sum, while agencies derive their power to determine what delegated rule- and policymaking will be binding or not from their statutory mandates, they exercise that power under very loose legislative constraint in many cases. Thus, the Panel's notion that a mandatory legal instrument must be one independent or autonomous from higher legislation simply misunderstands what determines whether agency policymaking is mandatory or binding.

In sum, it is regrettable that the $\mathrm{AB}$ did not take the occasion to overrule explicitly the Panel's finding that to mandate of itself a course of conduct, a legal instrument must be independent or autonomous from other legislation.

The $\mathrm{AB}$ did, however, go on to find fault with other aspects of the Panel's characterization of the Sunset Policy Bulletin as non-binding.

2 Strauss, P. L. Publication Rules in the Rulemaking Spectrum: Assuring Proper Respect for an Essential Element, 53 Admin. L. Rev. 803 (2001).

${ }^{3}$ See the criticism by Howse and Neven of a panel report that adopted a similarly rigid approach where the question was the practice of the Canadian Export Development Corporation, "Canada-Export Credits and Loan Guarantees for Regional Aircraft (WT/DS222/R): A Comment,” ALI Reports 2003.

4 Mendelson, N. A. "Agency Burrowing: Entrenching Policies and Personnel Before a New President Arrives" 78 NYU. L. Rev. 557, 573-576 and accompanying footnotes (2003). See also, Bressman, L. S. "Schecter Poultry at the Millenium: A Delegation Doctrine for the Administrative State," 109 Yale L.J. 1399 (2000). 
First of all, the $\mathrm{AB}$ held that the Panel had over-relied on wording in the introductory sections of the Bulletin that referred to its role as "guidance" and did not conduct "any in depth consideration of the impugned provisions of the Bulletin." (AB Report, para. 95). Here the AB was in part right and in part wrong. If what the $A B$ meant was that the language "providing guidance" was sufficient in itself to establish the non-binding or non-mandatory character of the Sunset Bulletin, then the AB was right. If what it meant was that in all cases the introductory description of a policy instrument's role would not be dispositive of whether it was mandatory, then the $\mathrm{AB}$ was probably wrong. Consider, for instance, the FAA's Advisory Circular on Minimum Flightcrew: the circular is stated to be "... not mandatory... It is for guidance purposes only." Had similar wording been used in the introductory section of the Sunset Policy Bulletin, the Panel would surely not have had to read any further to make a determination of non-mandatoriness. But it is important to note that, as with this aviation circular, where a policy statement is intended to be non-mandatory, the language of the instrument tends not to leave matters at stating that it is for guidance; usually there is additional wording to indicate the non-mandatory character of the instrument; in other words, agency practice suggests that agencies do not believe the courts will infer non-mandatoriness from the word "guidance" on its own. And this does suggest that the $\mathrm{AB}$ was right, in this case, that the Panel could not leave matters at considering the introductory wording of the Bulletin in isolation.

Then what other factors or considerations ought the Panel to have taken into account (besides of course the wording of the impugned provisions themselves)? One factor was whether the agency should "treat" the "rules" in the Bulletin as "binding." The AB appeared to take seriously in this regard Japan's notion that the consistent following of the Policy Bulletin in agency decisions could be evidence that the agency considered the Bulletin to be "binding." The Panel had relied on a statement by the United States in its memorial and oral argument, to the effect that the agency could depart from the Sunset Policy Bulletin as long as it gave reasons for doing so and was not acting in an arbitrary and capricious manner, as an indication that the Policy Bulletin was not mandatory; the $\mathrm{AB}$ suggested that the Panel should have considered whether the conditions for deviating from the Policy Bulletin were such as to make it "mandatory."

The $\mathrm{AB}$ also suggested that the Panel ought to have compared the contents of the Sunset Policy Bulletin with "contents of the 
corresponding statutory and regulatory provisions." The $\mathrm{AB}$ also suggested that in considering the specific provisions of the Bulletin impugned by Japan, the Panel ought to have looked at whether those provisions were "normative" in nature.

The approach of the $\mathrm{AB}$ tracks very closely the US case law. Thus in Doe v. Hampton, the DC Circuit made a number of observations that are similar or identical to those of the $\mathrm{AB}$ in its critique of the Panel's findings: (1) the focus must be on individual provisions of the legal instrument; even if most of the provisions are non-binding, some may nevertheless be mandatory; (2) the intent of the agency to be bound is a crucial consideration; (3) the intent of the agency is to be "ascertained by an examination of the provision's language, its context, and any available extrinsic evidence." 5

Having found that the Panel erred in rejecting Japan's claim that the Sunset Policy Bulletin "as such" violated the AD Agreement on the basis that the Sunset Policy Bulletin was not "mandatory," the AB went on to consider whether it should "complete the analysis."

The AB first considered Japan's claim that a provision of the Sunset Policy Bulletin violated the AD Agreement because it stipulated that the agency was to make a determination of the likelihood of future dumping on an order-wide, rather than a company-by-company basis. Here Japan's argument was that the provisions of Art. 11.3 of the $\mathrm{AD}$ Agreement were governed by Art. 6.10, which required that "as a rule," and where practicable, individual margins of dumping be assessed for each producer exporter or producer concerned. The AB agreed with the United States that this provision addressed itself essentially to the initial investigation and did not imply that a likelihood determination in a sunset review had to be done on a company-bycompany basis. As the $\mathrm{AB}$ noted, since there is no requirement in the first place under the $\mathrm{AD}$ Agreement to calculate dumping margins in making a sunset review, the provisions of Art. 6.10 invoked by Japan were, in this respect, simply not applicable to sunset reviews.

Having found that there was nothing in the $\mathrm{AD}$ Agreement that required a company-by-company determination of likelihood in a sunset review, the $A B$ then said it would "return to the measure at issue,..." As a matter of judicial economy, if the $\mathrm{AB}$ were applying the mandatory/discretionary distinction, it would have stopped before its "return to the measure at issue." Once the $\mathrm{AB}$ found that nothing

5 Doe v. Hampton, 566 F.2d 265, 280-281 (1977). 
in the $\mathrm{AD}$ Agreement required a company-by-company approach, Japan's claim failed, regardless of whether the provision in the Sunset Policy Bulletin setting out "an order-wide" approach was mandatory. If it was mandatory, it was not mandating anything contrary to the AD Agreement.

Yet the $\mathrm{AB}$ went on to make a point of the fact that the Sunset Policy Bulletin section in question stated that "the Department will make its determination on an order-by-order basis." The $\mathrm{AB}$ noted that the Bulletin did not provide any exception to this provision and that the use of the word "will" suggested that the agency was strictly limiting its discretion. The $\mathrm{AB}$ further observed that other provisions of the Bulletin used the more qualified phrase "normally will." Finally, the $\mathrm{AB}$ pointed to the fact that the United States itself had not suggested that the agency could deviate from an order-wide approach, or that it had ever done so in practice.

But the $A B$ did not say what these facts pointed to - whether they established that the provision of the Sunset Policy Bulletin was mandatory or whether they established that the provision, because of its likely impact on future behavior, would be capable in principle of "as such" violating relevant provisions of the AD Agreement, whether or not it was "mandatory" in the strict sense.

Japan had also claimed that the Sunset Policy Bulletin violated the AD Agreement because certain rules or guidelines in the Policy Bulletin "restrict USDOC in a sunset review, to considering only two factors, namely historical dumping margins and import volumes, and set forth mechanical rules creating a bias in favor of an affirmative likelihood determination." (AB Report, para. 170). While the Policy Bulletin also allowed other factors to be considered when there was "good cause," Japan considered that a showing of good cause for consideration of other factors was, in practice, a very significant hurdle, such that the process was, in Japan's words, "biased."

In deciding whether to complete the analysis, the $\mathrm{AB}$ formulated the legal question it would have to answer if it were to do so, as "whether [the provisions concerned] instruct USDOC to treat dumping margins and/or import volumes as determinative or conclusive, on the one hand, or merely indicative or probative, on the other hand, of the likelihood of future dumping." (AB Report, para. 178).

The $\mathrm{AB}$ noted that the use of the adverb "normally" in the Sunset Review Bulletin suggested that the agency could take into account other considerations in making its determination; on the other hand, 
Japan asserted that, in fact, this never did occur in practice. The United States contested Japan's factual claim here, arguing that it had "terminated many duties at the stage of sunset review," (AB Report, para. 183), and that statistics that suggested that importers and foreign producers always lost when at the sunset review stage could not substitute for an examination of the manner in which the evidence was weighed in each individual case by the agency. The $\mathrm{AB}$ then noted that, clearly, there were contested facts, and these could not be resolved by referring to any factual finding of the Panel below; since the $A B$ then could only complete the analysis by engaging in fact-finding itself, the $A B$ found that it could not complete the analysis.

The AB's refusal to complete the analysis shows its rejection of the mandatory/discretionary distinction as a mechanical metarule of state responsibility. If the $\mathrm{AB}$ viewed the mandatory/discretionary distinction as such a rule, it could easily have completed the analysis: in and of itself, the presence of the qualifier "normally" in the relevant provisions of the Sunset Bulletin would have constituted sufficient evidence that the provisions in question were "discretionary," i.e. as a formal matter, the agency could deviate from the guidelines. By contrast, the $\mathrm{AB}$ did not regard the clear grant of a margin of discretion through the qualifier "normally" as dispositive of whether the Sunset Bulletin "as such" engaged state responsibility under Art. 11.3 of the AD Agreement.

Beyond legal form, the crucial question for the $\mathrm{AB}$ is whether in fact a treaty provision gives rise to, or is likely to give rise to, a "consistent pattern" of conduct or practice in violation of the WTO treaty norms. In most respects, this approach seems to be an embrace of the spirit, if not the methodology as well, of the Section 301 ruling. Legal pluralism triumphs over positivism: formal legality does not exhaust, and may actually misrepresent, normative impact - the capacity to influence and structure a pattern of human conduct.

There is an odd Leo-Strauss-like esotericism to the manner in which the $\mathrm{AB}$ deals with the mandatory/discretionary distinction in this case. The $\mathrm{AB}$ shouts from the rafters that it will avoid dealing with the validity and meaning of the distinction, and then, implicitly or surreptitiously, through the way in which it criticizes the Panel below, and then how it makes its decisions on completing the analysis, relegates the distinction, at least as understood through the positivist lenses of many Panel rulings pre-Section 301, to virtual oblivion. Sometimes one can appreciate the subtlety and even obscurity of the $\mathrm{AB}$ - such techniques may be justifiable where the legitimacy stakes are very high and there is 
a serious political conflict underlying different positions in the case (Asbestos, Generalized System of Preferences (GSP)) - but why here? Why not come out and say directly that whether there is formal mandatoriness or an element of discretion is simply one ingredient, and not always the most important one, of an inquiry into state responsibility for compliance with specific provisions of the WTO treaties?

\subsection{Is the Sunset Policy Bulletin an "administrative procedure" within the meaning of Art. 18.4 of the AD Agreement?}

Instead of turning to the specific obligations at issue to determine the nature of state responsibility, and allowing the nature of those obligations to control the relevance of the mandatory/discretionary distinction, the Panel below did the opposite: it read the distinction into the text, as if it were a metarule that structured state responsibility with respect to all WTO treaty provisions, regardless of the text itself. Thus, in interpreting Art. 18.4 of the AD Agreement, which requires Members to "take all necessary steps, of a general or particular character" to ensure that their "laws, regulations and administrative procedures" are in conformity with the obligations in the $\mathrm{AD}$ Agreement, the Panel held that the Sunset Policy Bulletin could not be an "administrative procedure," on account of the Panel's previous holding that the Bulletin was not "mandatory."

In addressing this finding, the $\mathrm{AB}$ first noted that "Taken as a whole, the phrase 'laws, regulations and administrative procedures' seems to us to encompass the entire body of generally applicable rules, norms and standards adopted by Members in connection with the conduct of antidumping proceedings." (AB report, para. 87). The AB further noted that, "If some of these measures could not, as such, be subject to dispute settlement under the Anti-Dumping Agreement, it would frustrate the obligation of 'conformity' set forth in Article 18.4." The AB went on to note that the Panel had defined an administrative procedure as "a pre-established rule for the conduct of an anti-dumping investigation" (Panel report, para. 7.134); the $\mathrm{AB}$ did not find this definition as in error, but rather it objected to the Panel's assumption that a "rule" meant a "mandatory rule." Instead, according to the $A B$, the Panel needed to consider the "normative nature of the provisions of the Sunset Policy Bulletin and to compare the type of norms the Commerce Department was required to publish in formal regulations with the type of norms it could set out in policy statements." The question, then, 
for the $\mathrm{AB}$ was whether the normative effects of the Bulletin were similar or analogous to those of formal rulemaking.

\section{Economic issues}

We identify and evaluate two key economic questions that arise in the AB's Report on the US Sunset Review of Anti-Dumping Duties. First, how is dumping calculated in the Sunset Review? And second, how is the likelihood of continued or renewed dumping assessed? We consider each question in turn.

\subsection{How is dumping calculated in the Sunset Review?}

A first issue confronted by the $\mathrm{AB}$ in US Sunset Review is to assess the range of appropriate methods for calculating the dumping margins for use in a Sunset Review of anti-dumping orders. The particular methodology at issue in this case is "zeroing."

In determining the likelihood of continued dumping in its Sunset Review, the United States utilized dumping margins that had been calculated as part of its administrative review which, as we discuss further below, is an administrative procedure for adjusting the level of anti-dumping duties that is separate from the Sunset Review. There is no WTO requirement that dumping margins must be used to determine the likelihood of continued dumping in Sunset Reviews (p. 46, 127). Nevertheless, the $\mathrm{AB}$ found that, if a methodology for calculating margins were ruled illegal for use in one part of the administration of anti-dumping law, then this methodology could not legally be used in another part of the administration of anti-dumping law, even if WTO rules did not mandate that margins must be an input in this other part of the administration of anti-dumping law (p. 47, 130). But as the AB did not have the facts to establish that the United States had actually used, in its administrative review calculations, the particular zeroing methodology that had been found illegal in EC - Bed Linen, the AB concluded that it was unable to rule on whether the margins used by the United States in its Sunset Review were in fact inconsistent with WTO law (p. 51, 138).

As for the economic issues raised by the use of a zeroing methodology when calculating dumping margins, an economic assessment of the legitimacy of zeroing can be found in Janow and Staiger (2003), and the same discussion applies here. We therefore refer readers to the relevant 
portions of that paper. ${ }^{6}$ The broad conclusion in that paper, however, is that it is difficult to evaluate formally the economic merits of zeroing, because there is not an accepted understanding of why dumping is to be "condemned" in the first place. This conclusion applies equally well to a consideration of the merits of zeroing in the context of margin calculations for the determination of the existence of dumping, as in the EC - Bed Linen case, or in the context of margin calculations for use in the determination of the likelihood of continued or renewed dumping, as in the Sunset Review that is the focus of the present analysis.

\subsection{How is the likelihood of continued or renewed dumping assessed?}

A second issue confronted by the $\mathrm{AB}$ in US Sunset Review is to assess the range of appropriate methods for calculating the likelihood of continued or renewed dumping. The first question is whether or not the likelihood determination must be made on a company-specific basis or can rather be made on an order-wide basis (p. 51, 139). The AB found as a matter of WTO law that it can be made either way (p. 56, 155). The second question is whether the rules set out in the Sunset Policy Bulletin establish a procedure for determining likelihood that is biased against a finding that the anti-dumping order can be revoked (p. 63, 170). We consider each question in turn.

First, should the likelihood determination be made on a companyspecific basis, or can it be made on an order-wide basis? At one level, it is difficult to assess the economic merits of permitting the likelihood determination to be made on an order-wide basis rather than a company-specific basis, without knowing the factual basis on which the likelihood determination is to be made in a particular case. For example, if the likelihood of continued or renewed dumping could be judged on the basis of common factors (such as exchange rate movements) that are outside the control of the individual companies named in the dumping order, then determining the likelihood of continued or renewed dumping on an order-wide basis by assessing whether the common factors that originally led to dumping are still in place would seem sensible. On the other hand, if the likelihood of continued or renewed dumping depends importantly on factors that are under the control of the individual companies named in the dumping order, then

${ }^{6}$ See pp. $124-128$ of Janow, M. E. and Staiger, R. W. EC-Bed Linen, in H. Horn and P. C. Mavroidis, (eds.), The WTO Case Law of 2001, Cambridge University Press, 2003. 
determining the likelihood of continued or renewed dumping on an order-wide basis introduces a "public good" dimension that has the potential to create a significant free-rider problem among the companies named in the anti-dumping order. This free-rider problem could in turn thwart the effectiveness of the Sunset Review process mandated in Art. 11.3 of the AD Agreement.

The simple point is, under a company-specific determination, each firm can internalize the benefit (termination of definitive anti-dumping duties) of potentially costly actions that would eliminate its reason for dumping and lead to a favorable Sunset Review, whereas under an order-wide determination, all firms are lumped together and each can "free ride" on the decisions of others to take these potentially costly actions. ${ }^{7}$ The free-rider problem can in turn reduce the likelihood that any firm will actually undertake the costly actions which might lead to the elimination of dumping and the associated anti-dumping duties, and in this way can thwart the effectiveness of the Sunset Review process.

${ }^{7}$ We observe that, even in the presence of order-wide Sunset Reviews, it would still be possible for individual companies named in an anti-dumping order to take actions which could eliminate the actual duties that they pay. This possibility is provided for in Art. 9 of the WTO AD Agreement, which stipulates that anti-dumping duties shall be no more than the margin of dumping, which typically (except as provided in Art. 6.10) varies from company to company. It might then be wondered whether the potential free-rider problem associated with order-wide Sunset Reviews that we have described above has significance: After all, a company can always take actions that eliminate the anti-dumping duties it faces, and what more could it gain from a favorable Sunset Review at that point anyway? There are two problems with this sanguine view. First, as we discuss further below, the results found by Blonigen, B. A. and Park, J. H. Dynamic Pricing in the Presence of Anti-dumping Policy: Theory and Evidence, American Economic Review 94(1), March 2004, pp. 134-154, suggest that the details of the administrative review processes under which the duty adjustments provided for in Art. 9 are made can (at least in the case of the administrative review process in the United States) create strong disincentives for companies to actually take actions to reduce the duties they face. And second, even if a company has succeeded in taking actions which eliminate its dumping margin and therefore the anti-dumping duty that it faces, it can still gain from a favorable Sunset Review, because a favorable Sunset Review terminates the administrative review process and, hence, the continuing risk of future positive-margin calculations and the implied anti-dumping duties. These so-called "investigation effects" have been shown to have significant impacts on trade volumes and prices (For example, see Staiger, R. W. and Wolak, F. A. Measuring Industry-Specific Protection: Anti-dumping in the United States, Brookings Papers on Economic Activity: Microeconomics, 1994, pp. 51-118, and Krupp, Corinne M. and Pollard, P. S. Market Responses to Anti-dumping Laws: Some Evidence from the US Chemical Industry, Canadian Journal of Economics, 29(1), February 1996, pp. 199-227). 
An analogy with reduced prison sentences for "good behavior" serves to illustrate the point. Imagine a prison in which the inmates faced the possibility of reduced jail sentences in exchange for good behavior, but where the behavior of inmates was assessed on a prison-wide basis and where the fate of all prisoners was determined as a group: either collectively their behavior was deemed good enough to warrant early release for all, or collectively their behavior was not deemed good enough to warrant such preferential treatment. Especially in a large prison with many inmates, such a collective evaluation sets up a very difficult public good problem for the inmates, and it is likely that (i) behavior would not improve much as a result of this incentive program, owing to the potential for "free-riding" on the good behavior of others, and as a consequence (ii) the inmates would not enjoy early release. But now suppose that each inmate is evaluated individually and, with evidence of good behavior, is given an individual early-release date. Under this alternative system, the public good aspect of the first system described above is eliminated. And because each inmate now internalizes the benefits of his own actions (i.e. good behavior brings early release, bad behavior prolongs jail time), it is far more likely under this alternative system that the behavior of substantial numbers of inmates would improve and those inmates would be released early.

Returning now to the case of dumping, it is sometimes maintained, for example, that companies dump on foreign markets when they have excess capacity and wish to sustain high prices in a protected domestic market. If conditions of excess capacity caused the dumping which led to the initial anti-dumping duties, then it would be sensible in a Sunset Review to assess whether conditions of excess capacity still remain when determining the likelihood of continued or renewed dumping. Consider then, the different outcomes that would likely arise in a Sunset Review depending on whether this review were carried out on a companyspecific or an order-wide basis.

If this determination were made on a company-specific basis, then any company that took steps to reduce its capacity to a level consistent with the elimination of (its own) dumping could expect a favorable Sunset Review. In such a circumstance, it might be expected that the majority or even all firms would undertake the costly actions necessary to eliminate their own dumping, and the Sunset Review would be effective as a means to phase out anti-dumping duties and the dumping that triggered these duties. 
On the other hand, if the determination were made on an order-wide basis, then any company that took steps to reduce its capacity to a level consistent with the elimination of (its own) dumping would raise only fractionally the probability of a favorable Sunset Review, because the order-wide determination would depend on the overall threat of continued or renewed dumping from all companies named in the original anti-dumping order, and hence on all of the capacity choices of the other named companies as well. In this circumstance, it might be expected that the majority or even all firms would fail to undertake the costly actions necessary to eliminate their own dumping, and the Sunset Review would fail to be effective as a means to phase out anti-dumping duties and the dumping that triggered these duties. ${ }^{8}$

As our discussion has illustrated, at one level it is difficult to assess the merits of permitting the likelihood determination to be made on an order-wide basis rather than a company-specific basis, without knowing the factual basis on which the likelihood determination is to be made in a particular case. But at a general level, we suggest that this difficulty is persuasive in indicating that a cautious view of the merits of permitting the likelihood determination to be made on an order-wide basis rather than a company-specific basis is called for. In particular, based on the concerns raised and discussed above, an argument can be made that the WTO legal text should be changed to require company-specific likelihood determinations in those Sunset Reviews where such determinations are feasible and not excessively costly relative to order-wide likelihood determinations, thereby introducing a presumption in favor of company-specific likelihood determinations in Sunset Reviews. We suggest, for the reasons discussed above, that this change could enhance the effectiveness of the Sunset Review process mandated in Art. 11.3 of the AD Agreement, and thereby hasten the phasing out of anti-dumping duties and the dumping that triggered these duties.

We now turn to the second question raised above: Do the rules set out in the Sunset Policy Bulletin establish a procedure for determining likelihood that is biased against a finding that the anti-dumping order can be revoked? In considering this question, the $A B$ noted (p. 63, 172)

${ }^{8}$ The recent empirical results of Olson, Kara M., Free Riders Among the Rent-Seekers: A Model of Firm Participation in Anti-dumping Petitions, April 15, 2004, unpublished manuscript, document important free-rider effects in the context of the anti-dumping filing behavior of US companies, suggesting that the kinds of free-rider effects emphasized above in the context of order-wide Sunset Reviews could also be quantitatively important. 
that the USDOC "normally will" make an affirmative determination regarding the likelihood of continued or renewed dumping if any of these three conditions hold: (i) dumping continued at any level above $0.5 \%$ after the issuance of the order; (ii) imports ceased after the issuance of the order; or (iii) dumping was eliminated after the issuance of the order and import volumes declined significantly. The logic of these rules is apparently a simple one: if dumping is still ongoing in the presence of anti-dumping duties, or if it has stopped but import volumes have declined significantly (or even ceased) as a result, then if definitive anti-dumping duties are terminated, dumping will likely continue (case (i)) or resume (cases (ii) and (iii)).

The $\mathrm{AB}$ had no problem concluding that the rules followed by the USDOC, as described just above, offered "indicative or probative" guidance for determining likelihood, but said that these rules should not be deemed "determinative or conclusive." (p. 65, 178). The AB then observed that there was insufficient evidence to conclude that the language in the Sunset Policy Bulletin made these rules determinative and conclusive, and so there was no as-such illegality associated with them (p. 69, 190). And the AB concluded that the USDOC's reliance on margins and import levels to determine likelihood in this case was sufficiently justified to point to likely future dumping, and so found that there was no as-applied WTO illegality associated with them. (p. 74, 205).

At a basic level, a meaningful assessment of the likelihood of continued or renewed dumping requires an understanding of two things: (i) what conditions led to dumping in the first place; and (ii) whether those conditions have changed in a way that removes the original reason for dumping. Somewhat astonishingly, neither of these two elements appears to play any real role in the USDOC's methodology for determining likelihood, or in the AB's assessment of the legitimacy of the USDOC's methodology.

Interestingly, because of the details of the administrative review process under US anti-dumping law (and presumably also of the administrative review processes of other countries that share these details), the continued existence of dumping margins in the face of antidumping duties is not necessarily indicative that dumping will continue if the anti-dumping duties are terminated. Specifically, an implication of the analysis of Blonigen and Park (2004) is that the administrative review process associated with US anti-dumping law can increase the incentive of a firm to engage in dumping, once it is faced with 
anti-dumping duties and is subjected to the administrative review process. This means that, even if the conditions that led the firm to dump originally are no longer in place, the firm may continue dumping as long as it is the subject of the administrative review process, because of the dynamic disincentive to stop dumping which is set up by the administrative review process itself under US anti-dumping law. And so, a firm that is currently dumping might, in fact, choose to stop dumping if the anti-dumping order were lifted. Blonigen and Park offer a theoretical model that is consistent with this kind of prediction, and then examine the data and find empirical support for their model. This suggests that the indicators used by the USDOC for determining the likelihood of continued or renewed dumping are problematic and unreliable.

To understand the findings of Blonigen and Park (2004), it is necessary to appreciate a few details of the way in which the administrative review process proceeds under US anti-dumping law. Under the US administrative review process, anti-dumping duties are potentially recalculated each year in light of the past year's pricing data. This means that, under US law, the amount of the anti-dumping duty that a company must pay is assessed on a retrospective basis. If it is found under an administrative review that the dumping duties faced by a firm in the previous year were higher than the dumping margins reflected in its actual pricing behavior during that year, then the firm is refunded the difference, and the duties for the current year are reduced to reflect this new (i.e. last year's) margin information. And conversely, if it is found under an administrative review that the dumping duties faced by a firm in the previous year were lower than the dumping margins reflected in its actual pricing behavior during that year, then the firm is billed for the difference and the duties for the current year are increased to reflect this new (i.e. last year's) margin information.

Presumably, the administrative review process under US antidumping law is put in place to allow firms "time off for good behavior," in the sense that it offers dumping firms an incentive to stop dumping and free themselves from anti-dumping duties. Yet notice that the retrospective nature of the assessed anti-dumping duties under the administrative review process makes it especially costly in the short run for a firm to actually get out from under anti-dumping duties once these duties have been initially imposed on it. The reason is that, to be free of duties beginning with next year's administrative review (and to receive the refund of duties paid this year), the firm must raise its price during 
this year to eliminate the dumping margin while still facing the existing anti-dumping duties for the year. This implies that its price to importers (and domestic consumers) during the current year must be pushed doubly high - so that, for example, a foreign company that faces a $40 \%$ anti-dumping duty this year must raise its price to importers and domestic consumers by an additional $40 \%$ for this year - and its sales during the current year must thereby be pushed commensurately low, if it is to rid itself of anti-dumping duties beginning with the next administrative review.

What we have just described is the dynamic disincentive to stop dumping which is set up by the administrative review process under US anti-dumping law. Evidently, especially for firms that do not care too much about future profits and are more focused on short-term profits, shedding existing anti-dumping duties under the US administrative review process can be very costly.

Interestingly, in their empirical work, Blonigen and Park (2004) find that the majority of firms do not decrease their dumping margins through the administrative review process, and a significant percentage actually increase their dumping margins over the review process. Blonigen and Park then argue that this can be explained formally as a consequence of the dynamic incentives set up under the US administrative review process. In particular, due to the retrospective nature of the assessed anti-dumping duties under the US administrative review process, as described just above, firms that do not care too much about the future and are concerned mostly with short-term profit levels will find it advantageous to raise their margins each year and dump more aggressively under the administrative review process, in order to offset the rising anti-dumping duties, until they are eventually driven out of the market by prohibitive anti-dumping duties. In fact, in their benchmark formal model, Blonigen and Park identify a critical rate at which a firm discounts future profits, and show that a firm that discounts future profits at a rate higher than this critical rate will choose to dump and then choose to raise its dumping margin in each year of the administrative review, while a firm that discounts future profits at a rate lower than this critical level will choose not to dump in the first place. In an extended formal model in which firms face uncertainty about the likelihood of initially being caught dumping, Blonigen and Park then show that some of the lower-discount-rate firms will now also be induced to take a risk and dump but, unlike their higherdiscount-rate counterparts, these lower-discount-rate firms, if caught, 
will then use the administrative review process to lower or even eliminate their dumping margins and thereby escape from antidumping duties through time.

It can now be seen that the results of Blonigen and Park (2004) cast serious doubt on the methodology of the USDOC for determining the likelihood of continued or renewed dumping. In particular, an implication of their results is that the following scenario is not implausible: (i) a firm initially faces conditions that lead it to begin dumping, and is then caught and faces initial anti-dumping duties; (ii) the original conditions that led the firm to choose to dump then change in a way that would remove the firm's incentive to dump if it could make the choice of whether to dump anew; but (iii) under the administrative review process that is subsequently triggered, the dynamic disincentive to stop dumping keeps the firm dumping into the future. Clearly, under such a scenario, interpreting existing dumping activity under the US administrative review process as indicative of the likelihood that dumping will continue if the anti-dumping duties were terminated (and along with their termination, the termination of the administrative review process) is problematic.

In light of this discussion, we return to our initial observation that a meaningful assessment of the likelihood of continued or renewed dumping requires an understanding of two things: (i) what conditions led to dumping in the first place; and (ii) whether those conditions have changed in a way that removes the original reason for dumping. We have suggested that neither of these two elements appears to play any real role in the USDOC's methodology for determining likelihood, or in the AB's assessment of the legitimacy of the USDOC's methodology. But if the Sunset Review provided for in Art. 11.3 of the $\mathrm{AD}$ Agreement is to have meaning, then it must require that a meaningful assessment of the likelihood of continued or renewed dumping is carried out.

It is important to point out that an assessment of the conditions that have led the companies named in an anti-dumping order to dump is not required by Art. 9.1 of the $\mathrm{AD}$ Agreement for the original imposition of anti-dumping duties. So our discussion indicates that a different criterion should be applied across Arts. 9.1 and 11.3. But we see no necessary inconsistency in this. While a requirement could have been included in the AD Agreement that the particular reasons for dumping must be articulated as a condition for imposing anti-dumping duties under Art. 9.1, there is no logical necessity that such a requirement 
must be included. By contrast, we argue here that an understanding and articulation of the conditions that led to dumping is logically necessary to assess the likelihood of continued or renewed dumping, and therefore is an implied condition for extending definitive anti-dumping duties beyond the five-year termination date that Art. 11.3 otherwise dictates. Thus we suggest that, while Art. 9.1 permits the imposition of antidumping duties without any assessment of the conditions that have led the companies named in the anti-dumping order to dump, the fundamental logic of Art. 11.3 indicates that an assessment of the conditions that led to dumping - and an evaluation that these conditions have not now changed - must be provided if a member government wishes to extend the definitive anti-dumping duty beyond the five-year termination date that Art. 11.3 otherwise dictates. We suggest that the $\mathrm{AB}$ erred in not requiring the United States to provide such an assessment as part of its Sunset Review. 